\title{
Youth Lifestyle in A Moslem Magazine: A Reception Analysis on "Muslimah" Readers
}

\author{
Airin Nisa, Ken Reciana, \& Billy K. Sarwono Atmonobudi
}

\author{
ABSTRACT
}

\begin{abstract}
This research is about whether or not Indonesian female youth Moslem are easily accepting religious values packaged with popular icons in a Moslem magazine. In this magazine, teenagers do not have to wear long, loose dark colored clothes, but they may wear light colored, tight and trendy dresses known as modern hijab. The main goal of this research is understanding female youths' reception over Muslimah magazine applying Stuart Hall's encoding and decoding approach. Primary data were collected by in-depth interview toward selected readers. The results are: (1) the ability of parents to control their teenagers' religious behavior affect teenagers' reading over Muslimah. (2) Informants who live with their parents-younger than 20 years old, and have strong connection with religious peer group - tend to build negotiated readings. (3) Informants who do not depend on their parents-older than 20 years old, and have professional jobs - tend to rely more on mass media for seeking religious information more than their peer group or parents. Therefore, they tend to agree with Muslimah coverage which emphasized more on modern Moslem youth lifestyle than on its syariah (religious values).
\end{abstract}

Kata kunci: muslimah magazine, hijab, jilbab, perception, recuption anaysis

\section{Introduction}

$J_{\text {Jlbab gaul }}^{1}$ (trendy veil/jilbab) is a trademark for majority of Islamic girls in many towns in Indonesia today. The term used to identify this kind of fashion, jilbab gaul (or trendy veil) more or less means fashionable veils which were regularly updated following fashion trend as well. This style, ${ }^{2}$ initially developed at 1995, was not rigidly measured toward Islamic values. Later on, the development lead to the birth of Islamic clothing fashion section in many mass media, especially magazines aimed for muslimah (Islamic women). (Juliastuti, 2003; Al-Ghifari, 2005).

Rojek (2000), further, described that media of- fered certain definitions concerning realities over 'the trendy' and 'the old fashioned (not trendy), about who could be an idol or not, what suggested to wear and which one is not, what kind of place should be attended and which one shouldn't, what activities give the most advantages, and which one is useless, and so on. Media potent as the main factor in constructing youth lifestyle derived from its ability to construct realities. Therefore, realities presented in media content become second realities which had been produced through some stages of selection and reproduction process. This 'constructed reality' is then being declared as the 'real' truth by media to serve its ideological purposes. Media which offered the ideas 
of popular lifestyle are not free from those tendencies. This happened not just on MTV, youth magazines such as Gadis (Girls), Kawanku (My Friend), CosmoGirl, or Cosmopolitan, but also on youth magazines based on Islamic values circulated widely in recent years.

At the beginning, media based-on-Islam discussed only political matters. This has made them unacceptable for the market and merely survived in a short time. At the end of 1980's, majalah Amanah which aimed women and Islamic family segment was published. The content was composed of $70 \%$ popular article, the rest was dedicated for Islamic teachings. Amanah was soon followed by publication of the same kind of magazines: Ummi, Noor, Paras, and Alia. The potent of youth audience market then resulted in the birth of Muslimah magazine. Muslimah was published with the same strategy as other magazines of its genre. But, Muslimah has different point to emphasize. Within its slogan "Youth Moslem Trend", Muslimah publicly emphasized its content on Islamic youth lifestyle closely enough with icons of populer lifestyle: fashion show, Islamic fashion boutique, Islamic music, Islamic celebrities, gender-opposite' relationship, and Islamic youth behavior today.

Viewed from its history, Muslimah magazine was started from some concerns toward Islamic youth. First, there were some tendencies at that time to limit Islamic youth's effort to know more about their religion. Secondly, it was obviously enough that religion is not a hot issue for Islamic youth - religious matters were uninteresting topic to be discussed for them. At first, this magazine was designed to consist of $60 \%$ news or Islamic teachings, while the rest was dedicated for popular articles. On later development, the composition was changed to be 50:50, because the editors decided to intensify and decorate fashion section. Fashion section become the main selling point and being regarded as something attractive for teenage. According to the management, this fashion element made Muslimah looks different compared with other Islamic magazine. Muslimah, which first published at August 2002, wants to bridge fashion-conscious-youth with young people who want to be an artist or top model without unmasking their veil.

Later on, mass media was regarded not only affected youth lifestyle, but also playing roles in fulfilling the spiritual necessities of their audience. Interestingly, Malik (2002) and Al Ghifari (2004) explained that Islamic youth lifestyle actually is not quite different with general youth lifestyle. Islamic youth lives are also being touched by mall and its products. They love shopping, have high mobility, idolized celebrities, even celebrated Valentine Days and Halloween which is actually unrelated with Islamic teachings. This kind of youth are also consuming magazine and newspaper, and highlighting beauty and jewelleries. In line with those characters, they embrace Islamic teachings using electronic means, such as 'pengajian'3 from virtual network. In its ideal form, pengajian must be conducted face-to-face to ensure clarity over who's being the teacher and who's being the student (Rullyantini, 2006).

\section{Research Problem}

Researchers are interested in discussing youth Islamic trademark presented by Muslimah magazine, due to the fact that this topic is basically marked an intersection between popular culture and religion which for a long time has been viewed as contradictory. Religion usually perceived as a group of beliefs concerning supranaturals and sacred things, packed with moral code, institutions, practices, values, and rituals, but on this case such attributes blended perfectly with popular culture emphasized on appearance and consumerism ( $\mathrm{http}$ ://en.wikipedia.org).

According to Rothenbuler \& Coman (2005:8), religion nowadays is not placed as dominant institution anymore. Today, complex forms of religiosity are reborn in modern societies using various modern resources, such as the media, and one can notice the interpretation of mass media as a macrosubstitute for religion - what Thomas defines as "more or less syncretized arrangements of an emerging media religiosity with a cultural dynamism of its own." This only meant that media could 
be functioning as religion institution substitute, due to its capability comprising the temporary and the eternal, the plane of the daily routine and the fundamental truths, it offers order and sense to the world we live.

It has been the researchers' concern that Muslimah magazine, flagged with slogan "Islamic Youth Trend", played a significant role to construct Islamic youth culture. The problem lies on the socialization itself-socialization in mass media always inevitably carried business interests. Such was also happened on Muslimah magazine. Thomas (Rothenbutler \& Coman, 2005:81-82) wrote that religion discourses by mass media known as non-religious institutions tended to explain religion as matters of information (journalistic) only, entertainment-oriented, and considering marketability as something very important. Therefore, the appearance of its representation "do not portray something but rather perform something ... and the aim is construction and not merely portrayal, ... in the end, the magazine was accepted by audience no more than because its attractiveness." .

Based on those explanations, the research questions were formulated focused on reception issues: how female Islamic youth, especially Muslimah reader, assigned meanings for the idea of Islamic lifestyle offered and shaped by fashion of this magazine? By following fashion advices suggested by Muslimah, do they feel that they have become 'Islamic' and have fulfilled their obligations as Moslem? Or do they feel that being fashionable and fulfilling obligations are something different? Is there any possibility for other signification concerning this matter? To answer those questions, the researcher would explained the matter utilizing encoding-decoding model or polysemic scheme developed by Hall (Tester, 1994:68). According to these models, producers create media texts in ways that encode a preferred or dominant meaning - the interpretation that will most likely follow from decoding based on the codes of the medium. Other people can develop negotiated reading or to construct an oppositional reading. The question is which groups produce negotiated or oppositional meanings. However, in communication, matters concerning the interpretation of text reading are not only just a part of meaning studies. It also addresses what we know now as reception studies.

Reception studies development begins with David Morley (Curran, Morley \& Walkerdine, 1992) who explains that positions, background and social role are the main mediators in decoding process, not as factors influencing the process but as key provider to decode a message. However, the result cannot be generalized constantly to predict a person interpretation. Therefore, Croteau (2003) adds other variables such age, race, ethnic, and gender which play a key role in providing us with cultural tools for decoding. Other related cultural tools were added by Morley, namely discursive resources such as concepts, languages and assumptions associated with a particular subculture and a certain political perspective. Consequently, different groups of people will have access to different discursive resources for decoding the media messages. The distinction between negotiated and oppositional readings is significant in this context, because oppositional readings require that audiences have access to discursive resources that allow them to make meanings opposing the preferred one.

Beside reception studies, this study also based on lifestyles concept suggested by Chaney (1996). While in the past, lifestyle is identical with ways in which one utilize his/her leisure time, or what their consider as important thing in their environment, nowadays, lifestyle is being understood as patterns of action which differentiated people from each other. The utilization of leisure time itself has become an industry covering fashion, recreation, hobby, housing, and much more. As industry, they try to attract targeted consumers with various glamorous and exclusively image as consumers heavily consumed the product being promoted. At the end, this lifestyle was developed and covered all human activities which characterized his/her identities and how other people perceived them.

Such problems could also be viewed from cultural studies perspectives. Curran, Morley and 
Walkerdine (1992) explained that media has potent ability to form culture due to the fact that media is served as source of knowledge and mediator which relate audience with many events on various places. It is from the media that audience gain knowledge, study norms, value, proper attitude, and so on. The three scholars argued that such formation is not instantly implemented. Nor do it directly appears on people action. This formation slowly sneaked on people minds by means of values formations. Moreover, Curran identified a bigger-scale-interaction, namely interaction between society culture and media which is being used to socialize that culture.

In social and cultural contexts, researchers in the field of British Cultural Studies observe news packaging. They explain that there is a relationship between news and myth because both function as accounts that uphold society's values and beliefs, and that also maintain ideological order as well as express it everyday in the news. Even John Hartley (2004) says news is myth maker. Therefore, it can be argued that news concerning trendy jilbab among Islamic youth is related with mass media ways to popularize Islamic youth myths, i.e. guys/girls who are wearing jeans, being successful in school, and going to social places for hanging around but still feeling obliged to cover their 'aurat'4.

\section{Research Methodology}

The methodology being employed in this research is phenomenology (Patton). There are some criteria developed for purposive informant, namely: veiled Islamic youth, aged 13-25 years old, reading Muslimah more than a year. According to Alif (1996), the span of youth age was divided into three cathegories: (a) teenager; (b) young adult, 20-25 years old; (3) maturely adult, 26-35 years old. Informants were selected based on non-random procedure (Jensen \& Jankowski, 2002). In order to obtain a good result, this research is using criteria given by Creswell (1994): employing thematic analysis as analyzing technique. Data was collected during 3 (three) months research period starting from March 1st until the end of May2006 at Jakarta.

\section{Data Findings}

\subsection{Informants Background}

The first informant (23 years old, junior high school graduatee) is a babysitter who worked in Jakarta. Previously, she had worked at Cirebon, Cilegon, and Kuningan (West Java). She completed elementary school as well as junior high schoolboth in public school. Her parents paid not too much attention toward socializing religious values for their children. Nor did her peer group that hardly conducted religious order. According to her, her relationship with her parents was not good. For her, her uneducated parents were rigid, authoritarian which prevented her to unreveal her problem to them. At the age of 8 years old, she was raised up by foster parents who introduced her with religious values until she reached the age of 13 years old. At the year of 2000 , she attended a babysitter course, during which she made friends with some acquintances with strongly religious faith. Then, she started to wear veil. She subscribed Muslimah since its first edition. She also subscribed three other Islamic magazine, and consumed Islamic books related with household and enterpreneurship.

Second informant (22 years old, finished three-years-diploma) worked as a nurse in a small clinic located on the edge of Jakarta. She lived with her mother, and never had any education in Islamic-based school. Her parents were divorced in her childhood, and this breakup led her mother to work. A neighbour took care of her while her mother worked. Similar with the first informant, her parents also paid no attention to socialize Islamic values. She attended pengajian if there's still any time left. Influenced by her friends, she started to cover her head with jilbab (veil) at the age of 17 years old. A friend, then, introduced her with Muslimah, an Islamic youth magazine. Fashion section became her favorite for being responsible to keep informing her about how to perform fashionably by her new looks (with veil!).

The third informant (16 years old, 2nd grade on senior high school) live with her family. Her hobby is writing short stories - one of them was 
published by Muslimah. She attended Islamicbased school (both elementary and junior high school), her parents raised their children strictly (with Islamic teachings). She joined Kalam in her school, apparently, started from last year, she wore jilbab. Her parents adviced her to make friends only with good people, religious one. She was asked for behaving well, being extrovert, wrapped her physical appearance with jilbab. Initiative to subscribe Muslimah came from her mother. She preferred Gadis (popular girl magazine) at that time.

The fourth informant (19 years old, student) was raised in a village in Tegal, Central Java, a product of high-ranking school. She was the youngest of nine children in her family. As far as she knew, her mother had wore Islamic clothes since her childhood, and this was followed by her six sisters since they entered senior high school. The Islamic clothes milieu was familiar to her, and later on led her to do the same when she entered senior high school. According to informant 4, her mother raised their children with strict religious value. Her family, she remarked, is religious enough, simple in their household living - she and other children in the family were not allowed to wear strangely striking clothes. Her time was mostly spent on campus, during which she busied herself with religious activities such as attending discussion in Islamic Studies Forum, participating in Islamic Basic Studies for new students in her campus, monthly pengajian, and other forum of exchanging ideas. She also occupied herself with community works, such as giving free-training and learning-assistance for a Sunday school located at Cipayung.

\subsection{Informants View Concerning Islam}

For daily matters, the first informants argued that instead of being rigidly conducted, Islamic teaching must be flexible in practice. Nobody could conducted Islamic way of life perfectly. The most important thing for a Moslem, according to her, is seeking mercy from God and not repeating his/her mistakes.

The second informant is talking about the importance of logics in practicing religious val- ues. She said, "I'm always employing logic in practicing (Islamic) teaching. For example, if [one] said that you must behave like this or that, I have to know first, from which sources those sayings are comes? From Al Quran, or Al-Hadith? ... First, I should examined the logic of such practices: what's the cause? What are the advantages of doing such act?"

For the third informant, Islam is the foundation of all matters of life. She explained, “... from several sources (concerning Islam), Islam actually is very flexible, we could gain everything (the regulations, norms, values, etc.). The problem probably lies on human itself, that's all." Meanwhile, according the fourth informant, religion is the foundation of preaching, manner, and the right belief (aqidah).

The span of informants' views indirectly reflected their self identity which is wanted to be displayed among others. We can see that the first informant wants to appear as a smart religious woman who able to take care of herself. The second informant, suggested by her view about Islamic teachings, wants to be perceived as moderate Islam, meanwhile the third informant who relatively younger than other informant tends to display herself as flexible (girl) for religious matters and modern socialization. For her, "my veil is long, but it only served as a tool to cover myself. Actually, I'm flexible." Obviously enough, third informant wants to appear not as 'strict' as her look. She definitely wants to show her self identity similar with other girls in general. These differences seemed quite obvious compared with the fourth informant, a student of the University of Indonesia, who said that the most important matter in conducting her daily life activities is practicing her religious righteously. She also wants to be viewed as somebody who "... is not too stupid in intellectual aspect, has great motivation to learn, is having good relationship with others, and open for any segment variation."

It could be suggested that informants' religious perspective and self image become the basis of their perception toward their chosen Moslem clothes. First informant tends to follow 
fashion trend for her clothing. It appears on her veil combined with long blouse, or clothes with loose skirt. For certain occasions, she even imitated veil model as suggested in Muslimah (labeled as 'trendy' model). The second informant tends to choose short veil, body-fitted clothes but not too tight, bright colored fabric which looked 'modist', combined with much variations for veil. She consider that veil which were tied on her back is convenient. By this kind of veil, she hoped that other people would perceive her as being moderate in religious matter. Informant three loves long veil which covering her upper body but no more than waist, combined with loose clothes and skirt. Such model served religious order concerning clothes as well. She doesn't like to follow a mix-nmatch Moslem fashion or any veil modification. It was impractical, and she feels unadjusted with fashion trend like that - she perceived herself as 'not modist.' Similar with the third informant, informant four explained that she prefer long loose veil, covering her breast, combined with loose clothes fashion, "... and must not attracted anybody."

\subsection{Meanings Assigned by Informants toward the Use of Trendy "Jilbab" and Its Representation in "Muslimah" Magazine}

Generally, the first informant argued that there's no problem in practicing Islamic lifestyle for young people. She said:

"Well, in this era, it's really hard [to live with purely Islamic standard way of life]... whether you like it or not, we tend to be influenced [modern standard way of life]. On the other hand, if we want to conduct our life purely (within Islamic standard, very religious standard'), it must be supported with certain communities (she meant an exclusive community which closed itself to other community whose background or ideas is different with themselves)."

On the contrary, the second informant viewed that people nowaday is not necessarily wearing jilbab based on their consciousness toward religious values. It could be due to the trend only.

"Today fashion figure seemed only follow the trend, for example, because her hair is not looking good, she tried to cover it with veil. Therefore, she wore it arbitrarily. Instead of covering the neck (as ordered by Islam), many seemed ignore that order.. it become a trend that Islamic women must wear veil..."

The third informant seemed hesitate with her own opinion. For her, the most important thing is trying to adjust herself with popular forms developed among society and her own peer group environment. Her impression toward Islamic girl wearing long veil is expressed in this statement, "People perceived them as different ... an extremist (fanatics)... unable to socialize with other, close-minded, close his/herself..." The fourth informant actually has similar feelings with third informant, that long veil is old fashioned and extreme-looking. Today's jilbab is not necessarily covering breast, but she felt that jilbab like that, although updating the world trend, must not be allowed.

Here are some informants' signification toward Muslimah magazine which are interesting to be discussed. The issues are clustered in three points, concerning: (a) The ideal 'Muslimah (Islam women)': Islamic youth wearing jeans, succesfully learning in school, hanging out on social places, but still feeling obliged to cover 'aurat'; (b) Skills and achievements offered by Muslimah, such as beauty class, Muslimah top model, and Acting Clinic; (c) The usage of trendy jilbab (see the table on next page).

Concerning the ideal woman of Islam, the first informant to the third informant have nearly similar views about the importance of attitude balance between religion/faith and daily activities which is reflected on girl behavior. According to them (Table 1), extensive association activities is important for youth's daily lives. In order to be acceptable in such situations, trendy jilbab served well as an indicator to display their neutrality or flexibility. At least, by wearing trendy jilbab, it could made them appeared not being too fanatics or belong to any extreme group.

The fourth informant has deeply religious view, more than other informants. For her, ideal girls of Islam are typically those who hopefully 
could be socializing their religious values in daily practices, and not solely judged by their clothes or jilbab or any typical relationship.

Quite interesting findings also appeared on 2nd column of the table, discussing skills and abilities offered by Muslimah magazine to their audience related with beauty, self-care, and other skills considered important for girls later for their household. About this, all informants agreed that such skills could be an advantage for them today or after they get married and become housewifes. This view even seemed rational enough for informant 4, who always being educated in best school and often generating critical opinion. For her, domestic sector is an ideal domain for Moslem women, as reflected on her reply answering the most important traditional role for women. The ideal women, according to her, is those who can maintain good relationship in her family. If a woman is doing make-over to beautify herself, it should be done for the sake of her husband, and not for her self-confidence or self-interest.

The third column is filled with meanings assigned by informants toward the ideal representation of women as appear in Muslimah. Seemingly, their perspectives concerning ideal girl influenced their meaning-making. It is obviously that the different perspectives among the first and second informants have resulted in different meanings. The first and second informants try to comprehend religion by way of rational thinking. They build dominant belief about the importance of balance between religion and social activities. On the contrary, the fourth informant which believes that Islam is basis for all activities, and actively engaged in many religious activities, assigned oppositional meanings.

An interesting finding to be noticed is mean-

Tabel 1: Informants Perception Toward Popular Youth Moslem

\begin{tabular}{|c|c|c|c|c|}
\hline & $\begin{array}{l}\text { Ideal women in Islam } \\
\text { According to Informants }\end{array}$ & $\begin{array}{l}\text { Skills and Abilities of Youth Moslem } \\
\text { Represented by Muslimah Magazine }\end{array}$ & $\begin{array}{l}\text { Meaning Assigned by Informants } \\
\text { toward Ideal Muslimah (Islamic } \\
\text { Women) as Represented by Muslimah } \\
\text { Magazine }\end{array}$ & \\
\hline $\begin{array}{r}\text { Infor } \\
\text { mant } \\
1\end{array}$ & $\begin{array}{l}\text { Preaching without altering } \\
\text { youth image. There must be } \\
\text { balance between preaching } \\
\text { and socializing. }\end{array}$ & $\begin{array}{l}\text { It is okay for Moslem youth to adopt skills offered } \\
\text { by Muslimah. These were considered better than } \\
\text { spent useless times in mall. }\end{array}$ & $\begin{array}{l}\text { Islamic youth represented by Muslimah } \\
\text { is mostly fitted for today's world. } \\
\text { Muslimah has been preaching/deliver } \\
\text { religious message without altering } \\
\text { adolescent image. }\end{array}$ & $\begin{array}{l}\text { Prefe } \\
\text { rred }\end{array}$ \\
\hline $\begin{array}{r}\text { Infor } \\
\text { mant } \\
2\end{array}$ & $\begin{array}{l}\text { Updating developing trend. } \\
\text { Islam and the life of youth } \\
\text { could be combined perfectly } \\
\text { harmonious. }\end{array}$ & $\begin{array}{l}\text { Beauty class considered as a good thing and } \\
\text { corresponding with Kartini hopes. }\end{array}$ & $\begin{array}{l}\text { Muslimah provided its reader with } \\
\text { guidance and views concerning today's } \\
\text { way of life. People must survived } \\
\text { against the impairment of the world } \\
\text { today. }\end{array}$ & $\begin{array}{l}\text { Prefe } \\
\text { rred }\end{array}$ \\
\hline $\begin{array}{r}\text { Infor } \\
\text { mant } \\
3\end{array}$ & $\begin{array}{l}\text { Being an Islamic women must } \\
\text { not necessarily become } \\
\text { rigid/extreme. Instead of } \\
\text { strictly following religious } \\
\text { values, Islamic woman must } \\
\text { be flexible and acceptable by } \\
\text { her environment. }\end{array}$ & $\begin{array}{l}\text { Activities depicted by Muslimah is good, for } \\
\text { example Muslimah in cooperation with Ristra } \\
\text { cosmetics. }\end{array}$ & $\begin{array}{l}\text { Muslimah depicted religious woman } \\
\text { who able to socialize in larger setting } \\
\text { Concerning the model of jilbab: didn't } \\
\text { like variations on veil, or heavy } \\
\text { decorated dresses; press-body-clothes } \\
\text { must not be adopted. }\end{array}$ & $\begin{array}{l}\text { Nego } \\
\text { tiated }\end{array}$ \\
\hline $\begin{array}{r}\text { Infor } \\
\text { mant } \\
4\end{array}$ & $\begin{array}{l}\text { Good relationship with family. } \\
\text { Has motivation to deliver } \\
\text { Islamic values to others. }\end{array}$ & $\begin{array}{l}\text { Beauty class skill is important for woman. It must } \\
\text { be learnt especially for the sake of husband, so } \\
\text { that there's no reason for husband to flirt with } \\
\text { other woman. But such articles (concerning } \\
\text { beauty class) are not necessarily appear on every } \\
\text { publication. Muslimah must brought to its reader } \\
\text { other skills for woman, something that could be } \\
\text { used for making money by producing something } \\
\text { saleable, so that every girl could supported herself } \\
\text { independently. }\end{array}$ & $\begin{array}{l}\text { Expressing concern toward Muslimah } \\
\text { content which emphasize more on } \\
\text { fashion. If Muslimah wants to invite its } \\
\text { reader to adopt Islamic girl clothing } \\
\text { style, it should offering fashionable } \\
\text { dress designed to cover women's breast. }\end{array}$ & $\begin{array}{l}\text { Oppo } \\
\text { sition }\end{array}$ \\
\hline
\end{tabular}


ings assigned by the third informant. Basically, the third informant's perspective is not too far different with the first and second informants. But, this perspective resulted in different assigned of meaning. This could be understood due to her daily experience, primarily on her religious activities which is different with the first and second informants. As a big-town girl, informant number three believed that Islamic youth must actively engaged and acceptable in any social situation. Therefore, trendy jilbab representation in Muslimah magazine is acceptable for her. On the other hand, her strong religion belief made third informant slightly disagree toward Islamic girls which wear tight clothes and jilbab merely as a means to update themselves with fashion trend, instead of inner calling to obey religious order. Her reception toward trendy jilbab representation could be cathegorized as negotiate meaning; in one hand, she agrees with the picture of ideal girl constructed by Muslimah as religious individual but easily getting along with other; on the other hand, she often disagrees toward various fashionable clothes offered by Muslimah.

\section{Conclusion and Discussion}

Following are some interesting findings to be discussed:

(1) Various past studies on audience meaningmaking confirmed the existence of such actions which were related with: (a) positions, backgrounds and social roles (Morley, 1980); (b) age, race, ethnic, gender, and perspective (Croteau, 2003); (c) social class, media production and media content, as well as audience interpretation (Press, 2003); (d) daily life experience (Press in Croteau, 2003); (e) past experience (Woodward, Acosta-Alzuru, 2002); and social context (Curran, 2002). This study has identified other important factors related with audience reception toward Muslimah magazine, namely life experience, peer group, parents role, and their religious perspectives. Obviously, the third informant and the fourth informant which belong to certain peer groups with intensive religious activities have gener- ated different meanings compared with the first informant and the second informant. Being students supported by their parents, even much younger than other informant, the third and fourth informants are relatively depended on their parents. Thus, parents control over them obviously played dominant role in their lifestyle. Such things aren't happened on the life of the first and second informants whose live were supported by themselves since each owned a regular job. In economical terms, they are independent from their parents. Moreover, these informants built poor relationship with their parents.

(2) Religious perspectives could be detected from the level of religiousity. Informants belong to adolescent cathegory or aged under 20 years old tend to gain upper religious level (or 'more religious') compared with those aged up to 20 years old. This assumption was clearly reflected on their religious activities break in their busy life as students. On the contrary, informants belong to young adult group have only a little amount of time to particularly attended religious activities. Religious perspectives, basically, also play a dominant role in meaningmaking activities for trendy jilbab represented by Muslimah magazine. This research is actually in agreement with the revisionist thinking (Croteau \& Hoynes, 2003) which clearly stated that audience meaning-making would resembled media news if (the news are) lies in the same direction with individual initial opinion. They whose religious knowledge based only on media news tend to build dominant meaning-making. Meanwhile, people with better religious knowledge tend to build negotiated, even oppositional reception.

(3) Informants in this research could be cathegorized in two domains: youth/adolescents and young adults. The behaviour and beliefs of informants belong the first cathegory is highly influenced by family and peer group. They gained their religious knowledge mainly from face-to-face communication. This was not happened on informants which belong to the 
second cathegory. Their attitudes and beliefs are influenced more by mass media (see Sarwono-Atmonobudi, 2004). They also generated their own money - thus, allowing them to be more freely in consuming products, including applying trendy jilbab offered by media. Being students, the first cathegory informant is still supported by their own parents, meaning that they still depend on their parents in terms of money. They need parents agreement before consuming anything to fulfill their needs - even to extend their religious knowledge.

(4) Almost all informants whose meaning-making process tend to be preferred and negotiated reading agreed that Muslimah is an Islamic youth magazine which fit the condition of this era. For them, popular Islamic lifestyle is the ideal way to bridge people necessities to be peacefully acceptable in socialization setting at large without ignoring religious values. From the concept of multiple readings offered by Hall, this research found that informants with highly religious activities has adopted oppositional readings. Inherently, they always want to socialize religious values in life experience. Such informants have higher level of education, attended better school in terms of quality, and therefore, built a considerable level of media literacy. Although accepted Muslimah as magazine based on religious values, they are able to see many interests being downplayed beneath the magazine.

(5) Although this research is not about gender, it seemed interesting enough to highlight the fact that Muslimah magazine which aimed to girls consistently represents women in their domestic area. This tendency is reflected on articles emphasize on topics such as progressive women appearance/performance, fashion, the importance of beauty class, cooking, and so on. Such emphasis are in agreement with typical Indonesian demand toward women which is bound to be around their house (see Sarwono-Atmonobudi, 2005). This research also marked another interesting finding: be- ing beautiful, or applying trendy jilbab become informants' effort in order to be accepted by society in modern environment- thus, derived not from their original necessities. Other than to accomplish their own satisfaction and individual gratification, social demand become something more important to be considered. For Mc Robbie, as well as Radway (Curran, Morley \& Walkerdine, 1992), as expressed in their study concerning women meaning making, it only meant that women is failed to be subject for themselves.

(6) In related with cultural studies, there are two matters could be explained. First, mass media has strategically taking advantage of religious symbol or religious icon for business interest. As also happened on Christmas celebration on every December which is marked by Christmas ornaments selling such as candles, trees, Santa Claus, and gift exchanges, such celebration made lost the essence of Christmas. Religious celebration are shifted to be merely something very glamorous. Without Christmas Tree, or other ornaments, most people found there are no Christmas at all to be celebrated. Such was also happened in the case of Muslimah who enjoying their success in presenting and producing the values and identity of popular Islamic youth through their mixmatch fashion section, and other activities reportage. Gone are the traditional way of wearing veils, in this modern era, according to Muslimah, jilbab must be something fashionable, trendy. Women who applied dark-loosely jilbab to cover their breast and shoulder ind order to adjust Islamic regulation are considered old fashioned, extreme, unable or reluctantly make friends or socialize with other, and close herself to public environment.

Secondly, Baker (2004) explained how adolescent period marked a transitional period from children to adults as seen on: (a) bigger responsibility for youth (although still under adult's control); (b) the appearance of rebellion phase toward cultural tradition passed for them; (c) youth, therefore, still need help, ad- 
vice, and professional support.

Mass media become something very important for youth due to the fact that media could served as information sources. As such, media is regarded as 'professional' and able to give many solutions and accomplish challenges rationally. Nonreligious media institutions even could be potentially shift the role of religious institution in order to socialize the value of life eternally. Through informative articles, news, and popular-nuanced-entertainment, informants feel to fit the lifestyle being represented by Muslimah.

(7) As business corporation, no wonder if Muslimah is business-oriented. But, one must intently observe any Islamic flag media, especially those which packed religion through popular culture icon, due to their way to relate with young reader as their audience. Obviously clear, there's any possibility for audience to build a so-called falseconsciousness, a term which is so popular of Marxist thinking. Three informants conceptually regarded the idea of popular Islamic lifestyle as an ideal form to live with, and wellcorrespond to modern era's demand. They didn't realize that such concept was exist due to market trend as expressed in Muslimah content adjusted to market demand. Hartley called this as a myth (2004) — the myth concerning Islamic popular youth who practice activities normally done by non Islamic youth, has extensive network of companionship, and developed shopping-on-mall hobby. They covered their awrah, yet noticeably fashionable enough to be looked at. The myth of trendy jilbab as veil model mostly recommended and fitted for today's youth has already accepted by many people. As consequences, women who applied dark, loose, and long veils nowadays are regarded as fanatics, extreme, and unpopular to associate with.

\section{Endnotes}

${ }^{1}$ Actually, there's a slight difference between jilbab and veil although both are known as ways to cover parts of body applied by Islamic women according to religious order. By definition, jilbab is woman's long, loose outergarment. (www.usc.edu/dept/MSA/humanrelations/ womeninislam/idealmuslimah/ Glossary.html), whereas veil is identified as head covering: a garment that covers the head and face (Wikipedia).In this paper, the researchers use both term (jilbab and veil) respectively as part of clothes to cover woman's hair and neck. 'Trendy jilbab' is a term developed in this research to serve research purposes, meanings veil/jilbab which is applied in a 'modern' and 'fashionable' touch.

2 It's not just about veils or jilbab actually, but concerning the whole Islamic clothing identified as "busana muslim" or Islamic dress.

3 Pengajian is a form of Islamic gathering where people read Al-Quran verses, sometimes also discussing its meaning and interpretation for daily lives or recent issues.

4 Aurat, or awrah, in Islam meanings body parts that should not be exposed. In traditional sense, for men it's from navel to knees, for women it's all part of the body except face and palms. In more recent interpretation, aurat could be anything that attract sexual desires from opposites gender which is forbidden in Islam. For some groups, voice and eyes sometimes are included as aurat.

\section{References}

Acosta-Alzuru, Carolina \& Peggy J. Kreshel. 2002. "I'm An American Girl ... Whatever That Means: Girls Consuming Pleasant Company's American Girl Identity." Journal of Communication. March 2002/vol 52 No.1. Wahington D.C: Oxford University Press.

Al-Ghifari, Abu. 2004. Remaja Korban Mode Bandung: Mujahid Press.

2005. Kudung Gaul. Bandung: Mujahid Press.

Alif, Gunawan M. 1996. Memahami Usia Dewasa Muda (Understanding Young Adult). Cakram Magazine, May. 
Barker, Chris. 2004. Cultural Studies: Theory and Practice. $2^{\text {nd }}$ edition. London: Sage Publication.

Chaney, David. 1996. Lifestyles: An Introduction (an Indonesian translation). Yogyakarta: Jalasutra.

Creswell, John W. 1994. Research Design: Qualitative and Quantitative Approaches, London, Thousand Oaks, New Delhi: Sage Publications.

Croteau, David \& William Hoyness. 2003. Media/ Society: Industries, Image and Audiences. $3^{\text {rd }}$ Edition. Thousand Oaks, CA, USA: Sage Publications.

Curran, James; David Morley and Valerie Walkerdine. 1992. Cultural Studies and Communications. London, New York, Sydney, Auckland: Arnold.

Effendy, Bachtiar. 2001. Teologi Baru Politik Islam. Yogyakarta: Galang Printika.

Jensen, Klaus Bruhn \& Nicholas W. Jankowski. 2002. A Handbook of Qualitative Methodologies for Mass Communication Research. New York: Routledge.
Juliastuti, Nuraini. 2003. "Politik Pakaian Muslim". Newsletter KUNCI number 13, Desember 2003. Accesed on 4 Januari 2006 from http:// kunci.orid. Cultural Studies Center.

Kurniawan, Junaedhi. 1995. Rahasia Dapur Majalah di Indonesia. Jakarta: Gramedia Pustaka Utama.

Louw. Eric. 2001. The Media and Cultural Production. London: Sage Publication

Malik, Abdul. 2002. Wanita Spons: Fenomena Wanita Masa Kini. Jakarta: Robbani Press.

Mu'nim, Abdul. 2000. Di Tengah Arus Transisi. Jakarta: Kompas Media Nusantara.

Patton, Michael Quinn (2002). Qualitative Research \& Evaluation Methods. $3^{\text {rd }}$ Edition. Thousand Oaks, CA: Sage Publications.

Rojek, Chris (2000). Leisure and Culture. London: St. Martin Press.

Rothenbuhler, Eric W; Mihai Coman (editors). 2005. Media Anthropology. London: New Delhi. Thousand Oaks: Sage Publication. 
